\title{
Dynamic comparative advantage analysis of rural and pastoral systems of small ruminant husbandry
}

\author{
Reza Pahlavani, Mohammad Ghahremanzadeh*, Ghader Dashti
}

Department of Agricultural Economics, Faculty of Agriculture, University of Tabriz, Tabriz, Iran

\section{A R T I C LE IN F O}

\section{Article history:}

Received 27 February 2017

Received in revised form

3 September 2017

Accepted 25 September 2017

\section{Keywords:}

Dynamic comparative advantage

Policy analysis matrix

Pastoralism

Panel data

Rural husbandry

\begin{abstract}
A B S T R A C T
Small ruminant husbandry is one of the most important and ancient economic activities in Iran's livestock subsector. In the three last decades, the productivity and profitability in this economic field has been reduced. During these years the government's support policy has been carried out. In this context, the purpose of this study is to analyze the dynamic comparative advantage in two ordinary systems for small ruminant husbandry includes rural and pastoral systems in selected provinces over 1997-2013 as panel data in Iran. We used several agricultural policy support indicators including Domestic Resource Cost (DRC), Social Cost Benefit (SCB), Effective Protection Coefficient (EPC), Nominal Protection Coefficient (NPC) and the dynamic Policy Analysis Matrix (PAM).The results suggest that both systems have dynamic comparative advantage, but the pastoral system has more. Reasons for increasing the dynamic comparative advantage in the pastoral system are: low fixed and variable cost, more using of growth season, more concentration of production management, expansion of market and ability of crops supplying in various markets. Therefore, the application of the policies such as scientific and efficient management, the balance between small ruminants and ranges, supporting and protecting natural resources and doing applied researches, are recommended.
\end{abstract}

(C) 2017 The Authors. Published by IASE. This is an open access article under the CC BY-NC-ND license (http://creativecommons.org/licenses/by-nc-nd/4.0/)

\section{Introduction}

Animal protein, especially meat protein, has an essential role in human's nutrition. Meat, especially mutton and beef, has an effective role in human health and food security. In Iran, the amount of per capita red meat consumption has reached from $11.08 \mathrm{~kg}$ in 2003 to 15.1 in 2013 (I.R. Iran Central Bank, 2013). A red meat whit 6.7 percentages has a great share in Iranian households' budget (I.R. Iran Statistical Center, 2014) and the growth rate of red meat production had been 1.1 percent from 2003 to 2013. The amount of consumption has increased from 505 thousand tons to 829 thousand tons during these years. At present, small ruminants produce almost 40 percentages of red meat in Iran (I.R. Iran Agriculture Ministry, 2013). This is produced from 66 million herds from which 28.9 million are in pastoral system and the rest are in rural system. Small ruminant husbandry is an old profession in

\footnotetext{
* Corresponding Author.
}

Email Address: Ghahremanzadeh@Tabrizu.ac.ir (M.

Ghahremanzadeh)

https://doi.org/10.21833/ijaas.2017.011.012

2313-626X/C) 2017 The Authors. Published by IASE.

This is an open access article under the CC BY-NC-ND license

(http://creativecommons.org/licenses/by-nc-nd/4.0/]
Iran. It has a great role in food security, general health, employment, population balance and occupation balance. In Iran eight million sheep are needed only for religious ceremonies (I.R. Iran Statistical Center, 2013). In Iran like other countries the interaction among environmental, economic and social factors has led to two systems for small ruminant husbandry: the fixed system (rural) and the moving system (pastoral). Rural system includes settling in villages and feeding the animal with supplementary forage. In this system husbandry is done alongside other agricultural activities. However, pastoral system is the subsistence base of 1.5 million individuals that has been formed during thousands years and is the continuation of primitive small ruminant domestication in open environments. Pastoralism is the only official system that uses ranges in the country (Tavakoli and Sayf, 2001). Pastoral life is in fact an ancient system for using less fertile and faraway lands. Both systems are distributed throughout the country. But this profession is more expanded in 4 provinces in western part of Iran including Lorestan, Kermanshah, Hamadan and Ilam provinces. Based on the agricultural consensus of 2013, these provinces have 9300 thousand herds small ruminant (sheep and goats); that is 13 percent of total small ruminant in 
Iran. The reason of selecting these 4 provinces is that they have both rural and pastoral systems in parallel and small ruminant husbandry has a basic role in the prosperity of their lives. In these provinces both systems are competing in using of resources.

Before last three decades, small ruminants were the main resources of meat production. But the dependency of this profession on ranges, unscientific and illogical management of grazing, recent dry years and lack of serious support for this profession, reduced the production of crops and its share in producing the red meat in country has decreased. This share is $40 \%$ now (I.R. Iran Agriculture Ministry, 2014). So it is essential that the basic study be done to discover the vulnerability and to introduce the best method for increasing the productivity and the economization of meat production. One of these studies is determining the dynamic comparative advantage in this economic profession. Since both systems are parallel and competition each other in using of common resources, evolution and comparing their dynamic comparative advantage can help designers and users to select the best economic method and help to increase the total factor productivity and profitability in this economic profession in the country. So, the main objective of this study is evaluation and comparing the dynamic comparative advantage in two ordinary systems for small ruminant husbandry includes rural and pastoral systems in selected provinces of Iran.

Today the crops production purposes are different in micro and macro level. In micro level, the aim of a producer is to get maximum profit, but in macro level is increasing the national crops supply, getting maximum social benefit and ability to present and competition in world trade. In this condition, sustainable of producing is depended on ability in competing in world markets. In addition, in each country, production must be profitable. In the other hand, the cost of production must be less than the payment for importing the same goods. In this condition, it is said that the zone or country has social benefit for the goods. This concept means comparative advantage in economics. Comparative advantage defines ability of a country or zone in producing the goods or services with less cost or more profit (Jairani, 2010). Ricardo (1828-1772) said, if a country has the advantage to produce one or more commodities, it must export those and import the other commodities. He emphasized on the main factor in production which is the labor force. Distributing the natural sources and production factors such as labor, capital and scientific information in different zones of world and also the difference between quantitative and qualitative of production factors, has led to this thought that, without foreign trade, the economic development is unavailable (Eslami and sherafatmand, 2013). Due to the importance of agriculture sector and livestock subsector, the government supports them for certain purposes every year. Supporting agriculture is effective in its increasing productivity (Hayes et al., 1995). The reasons for agriculture support are: 1- Its traditional role in food providing, 2- The economic nature of agricultural goods and their low supply and demand elasticity, 3- Its decreasing competition ability with other economic sectors, 4- Lack of unions and syndicates in it. So the application of government support policy is inevitable.

So far, the comparative advantage was determined for many of agricultural products by researchers in Iran and other countries. But dynamic comparative advantage was rarely studied in agricultural crops. For example, Gonzales et al. (1993) studied the comparative advantage (CA) of race, soybean, wheat flour and corn in Indonesia by using domestic resource cost (DRC) and nominal support protection (NSP) indices and the results indicated that only race and corn has CA. FAO (2001) determined the CA and price deviation in agricultural crops in Egypt by using DRC index. Funing et al. (2001) estimated the CA in cereal sector of China by using DRC index and the results showed that Japonica race, sorghum, medium Indian race, millet and Indian late ripen race have CA. In Iran, Julai and Jairani (2009), Dehghani (2003), Ashraphi et al. (2009) and Jairani (2010) had studied CA of agricultural crops. Bostaki (2009) has studied the effects of government interference in husbandry subsector in beef, chicken and eggs in (1982-1999). He showed beef had the highest and egg the lowest government support in Iran. Mehrabiboshrabadi (2009) determined the comparative advantage of agricultural crops in Kerman province by using policy analysis matrix (PAM). The results indicated that only wheat and Barley in Bardsir, Baft and Pea had comparative advantage. Dahmardeh (2010) studied the effects of government policy in selected agricultural crops in Sistan and Baloochestan province of Iran. Research showed that wheat and Barley did not have comparative advantage but watermelon, onion and tomato had it.

Based on these studies, many researchers have studied the effects of government interference. These studies include comparative advantage of agricultural products and estimating the government support policy based on Indices of organization for economic and cooperative development (OECD, 2007). So far rarely comprehensive research has been done on this subject, i.e. dynamic comparative advantage, in Iran. So this research is one of the first in agricultural crops. In addition, studying and comparison between pastoral and rural systems is essential to select the best method in small ruminant husbandry. This research is done for this purpose.

\section{Material and methods}

Comparative advantage is one of the strong laws in economics. This says that the production of a country or groups of countries, when is maximum that it has the least opportunity cost (Jalilpiran and Naserian, 2015). Establishing the comparative advantage is depended on technological, ecologic, 
humanitarian, management and political factors (Monk and Pearson, 1989). Except Ricardo that first introduced CA and applied it for labor force in agricultural sector, other economists began to complete the CA concept. Two Swedish economists Heckscher (1919) and Ohlin (1933) applied CA for other factors that are used in crops production. If all countries consider CA in crops producing, it will increase the welfare, because each country has CA in a commodity or more that can produce and sell it for them and get revenue. So the countries can exchange commodities between them and it can be one of the most important factors for the elevation of world welfare, this subject conducts production profit to equalization (Khandozi, 2013). If we consider the competition as a static element, progress and defeat in it depended on production in same time. But in today world, competition or advantage are dynamic and new production technology, new production process and new management concepts, cause to change or delete the CA that its example can be found in some countries. The reasons for these countries to pass static comparative advantage were the technological and scientific innovation, the expansion of foreign trade, and enlarging the scale of production and etc. They showed that dynamic comparative advantage can be established by increasing the experiences; capital, labor force or structural removing, and it can lead to economic development. Dynamic comparative advantage (DAC) is more precise than comparative advantage. It considers the changing of factors that affect in several years. In this research, it has been determined and compared the DCA in both systems of small ruminant husbandry (rural and pastoral). One of the methods that have been used for determining the DCA is Policy Analysis Matrix (PAM) that first has introduced and used by Monk and Pearson (1989).

This matrix is used for one year and so, one of the most protestation to it, is annularity. Because of CA is not fixed and many factors effect on it, so it cannot be static. Studying the annual government interference for one year cannot be right and cannot be applied by designers and planners, too. In this context, we must use dynamic policy analysis matrix. The PAM consist of two accounting identities, the profitability identities and the divergence identities, it has three fundamental rows. First row includes costs, revenues and profits at market price, second row shows these at shadow price and third row shows different between them. Third row in fact indicates government interference. Table 1 shows the Policy Analysis Matrix.

Table 1: The Framework of policy analysis matrix

\begin{tabular}{ccccc}
\hline & Revenues & Tradable inputs costs & Domestic inputs costs & Profits \\
Valued accounts at private prices & $\mathrm{A}$ & $\mathrm{B}$ & $\mathrm{C}$ & $\mathrm{D}$ \\
Valued accounts at shadow prices & $\mathrm{E}$ & $\mathrm{F}$ & $\mathrm{G}$ & $\mathrm{H}$ \\
Divergences & $\mathrm{I}$ & $\mathrm{J}$ & $\mathrm{K}$ & $\mathrm{L}$ \\
\hline & Source: Monk and Pearson (1989)
\end{tabular}

To determining the DCA, shadow and market prices are used. Shadow prices (social price) include universal or border line prices. Market (private) prices are the prices in internal markets. Market prices are formed by government policies. So each commodity has two prices, shadow and market prices. Many indicators are used for determining the CA, the first indicator is Domestic Resource Cost (DRC) that was used by Bruno (1972). DRC index is the ratio of domestic factors cost valued at social prices to the value added created by the same resources at social prices. If DRC index is less than one, so there is DCA, if greater than one, there is not DCA. Domestic resources are that cannot move and trade facility, such as earth, water, labor and some of the renewable resource. However tradable resources are the resources that traded and sold facility, such as many of physical inputs in agriculture such as fertilizers, forage, machines, drugs and etc. Social (shadow) prices are deviated by government interferences and are formed new prices that called market (private) prices (Abedi et al., 2009). If a commodity has more profit at shadow prices and less profit at market prices, it has paid indirect tax and if more profit has at market prices it has gotten subside (Mehrabiboshrabadi, 2009).

Based on Iran's Agriculture Statistic, the ratio of sheep number to goat is 4 to 1 ; so we consider a unit includes 80 sheep and 20 goats. This proportion is applied by many of researchers (Yarahmadi et al., 2005).

To establish PAM for each year and province, we have used data in that year and that province. To determine the Shadow prices for crops and tradable inputs we considered their international prices that for crops include FOB (free on board) prices and for inputs include Cost Insurance Freight (CIF) prices. The cost of transporting from borderline to provinces is gotten from the Organization of Terminal and Transport. To calculate the charge of decamping between winter quarters to summer quarter for pastoralists, we considered average distance for each province.

Since livestock decampment is inevitable and it is done in inter and intra provinces. Decampment is done by Lorries. Based on results of many study such as Jairani (2010) and Khademaolfazli (2010), 36 percentage of transportation charge is domestic and 64 percentages from it is tradable. To determining the shadow price (social price) of domestic inputs, we used the estimation of meat production function in framework of panel data. The prices for inputs are provided into time series for each province. Then was estimated suitable production function (CobbDouglas in here). In order to simplify the interpretation of result, we used logarithmic transform of data. Thus, the Cobb-Douglas production function is shown in Eq. 1. 
$\operatorname{Ln} Q_{i t}=\alpha+\sum_{j=1}^{n} B_{j} \operatorname{Ln} x_{j i t}+\varepsilon_{i t}$

where, $Q_{i t}$ is amount of meat in $i$ th province in $t$ th year, $x_{j}$ is $j$ th input including domestic and tradable that are used in meat production such as Feed, water, labor, animal drugs and etc., and $\varepsilon_{i t}$ is error term.

Since we had the panel data, in order to estimating the function production, first, we used Husman test to determining that it must be used Fixed Effect (FE) or Random Effect (RE) method. In FE method, intercept between crosses (i.e. provinces) is variable and there is not relationship between independent (exogenous) variable and error term. In this method, intercept only is variable between crosses and therefore time has not any effect on it (Molenberghs and Verbek, 2005). In Random effect method, each province has intercepted for itself. Eq. 2 presents this subject.

$\operatorname{Ln} Q_{i t}=\alpha+\sum_{j=1}^{n} B_{j} \operatorname{Ln} x_{j i t}+\mu_{i}+v_{i t}$

Based on Eq. 2, error term divided two sections, cross error term $\left(\mu_{i}\right)$ that there is not relationship between it and time and another stochastic term includes error term between time series and cross $\left(v_{i t}\right)$. In this model, is supposed that the terms of cross error has correlation with each other and between cross units and time series is not time correlation. Using OLS to estimating the parameters has consistent and without bias results but it has autocorrelation, so that we used Generalized Method Movements (GMM) to estimating the meat function production. Then we calculated the value marginal production (VMP) for each province and each year. The VMP is the shadow price of domestic inputs. After determining the shadow and market prices of tradable and domestic inputs and crops, the policy analysis matrix (PAM) was established for each province and each year in both rural and pastoral systems.

In order to determine the comparative advantage, we used the DRC index as following (Tsakok, 1990):

$D R C=\frac{G_{i t}}{E_{i t}-F_{i t}}$

where, $G_{i t}$ is the sum of domestic inputs cost, $E_{i t}$ is the value of incomes and $F_{i t}$ is the sum of tradable inputs cost to shadow prices, respectively.

Since in Iran the cost of many domestic inputs are determined in competition market and government don't interference them, so the private prices are same shadow prices for many goods. In this research, we have considered it. Then we established the PAM for both systems and for each province and each year. The sum of PAM for each system was 68 because the number of years was 17 and the number of provinces was 4 . So we have 136 PAM. Then with middling the amount of DRC index for provinces and years, the average of DRC calculated and compared in both systems. Then were calculated three other indicators for both systems and compared them each other. These indicators were effective protection coefficient (EPC), nominal protection coefficient (NPC) and social cost benefit (SCB). The EPC is gotten by Eq. 4.

$E P C=\frac{A-B}{E-F}$

where $A$ and $B$ are revenue and tradable inputs cost at market price and $E$ and $F$ are the same at shadow price, respectively. If it is greater than one, it means government has been supported it and if less than one, it means the government not only has not been supported but also the product has paid indirect tax. If EPC is equal one, this means government has not intervened it.

Nominal protection coefficient index (NPC) is gotten from Eq. 5.

$N P C=\frac{A}{E}$

If NPC is greater, equal and less than one, it means protection, noninterference and indirect taxing by government for it, respectively.

Social Cost Benefits (SCB) indicates the rate of cost to income, both at shadow price and is gotten from Eq. 6.

$\mathrm{SCB}=\frac{\mathrm{F}+\mathrm{G}}{\mathrm{E}}$

where F, G and E are cost of traceable, nontrade able (domestic) inputs and income at shadow price, respectively. If this rate is greater than one, it will show that it is not comparative advantage and when it is less than one it will mean there is comparative advantage.

Since we use the exchange rate to determine the shadow prices of the animal crops and inputs, and also official exchange rate (OER) is affected by government policies, we must use shadow exchange rate (SER). There are different methods for calculating of social exchange rate (SER). Three of these methods are:

- -Elasticity approach that was introduced by Krueger (1991)

- -Purchasing power theory that is calculated by rate the cost of one ounce of gold in internal market to that amount of gold in world market.

- -Standard covert factor (SCF) that is calculated by a correct factor that is gotten from low equation that official exchange rate is divided on it; its relationship is shown by Eq. 7 .

$C F=\frac{M+X}{M(1+T M)+X(1-T X)}$

where, CF is correct factor, $\mathrm{M}$, value of total imports to Cost Insurance Freight (CIF), X, value of total exports to free on board (FOB), TM, the mean of import tariff, and TX, the mean of export tariff, respectively. Then SCF is calculated as:

$S E R=\frac{O E R}{C F}$

where SER, OER, CF are social exchange rate, official exchange rate and correct factor, respectively. 


\subsection{Data}

This research that was done for evaluation and comparing the dynamic comparative advantage of small ruminant husbandry in rural and pastoral systems. It is carried out in four provinces in west of Iran including Lorestan, Kermanshah, Hamedan and Ilam. The time of research was 1998 to 2013. Thus, the framework of data is panel data. The provinces are the cross-sectional and the years are time series. Mentioned data is gotten from the Organization of Supporting the Livestock Affair, the Organization of Pastoral Affair, Central Bank, Statistic Center, Agriculture Ministry, Industry-mine and Trade Ministry, Power ministry in Iran and World Food and Agricultural Organization (FAO, 2016).

\section{Results and discussions}

According to the mentioned methodology, first, the market and shadow prices of tradable and domestic inputs and crops were provided. By estimating of production function, we determined the partial production elasticity of inputs and the
VMP. The VMP is the shadow price of domestic inputs. Since the shadow prices in both systems are common, we calculated them only for pastoral system.

Three inputs are considered, the amount of drug veterinary, amount of feed, and labor. The results of Husman test indicated that the calculated Chi-square statistic is 1.254 which not statistically significant. Therefore, we estimated the meat Cobb-Dauglas production function by RE methods with GMM approach and related results are presented in Table 2.

After calculating the sum of costs and revenues for each province and each year in both systems, the Policy Analysis Matrix was provided. The number of PAM was 136 (68 for each system). Then four indictors including DRC, SCB, EPC and NPC were calculated. In Tables 3 and 4 the total and the average of DRC, SCB and the average of EPC and NPC in both systems are shown. According to Table 3, the amount of DRC and SCB indicators in rural system is greater than pastoral system, so dynamic comparative advantage in pastoral system is more increasing than rural system.

Table 2: Result of estimating meat production function

\begin{tabular}{ccccc}
\hline Variable & coefficient & Standard error & t-statistic & probe \\
\hline Ln Veterinary & 0.568 & 0.210 & 2.70 & 0.007 \\
Ln Feed & 0.213 & 0.124 & 1.718 & 0.091 \\
Ln Labor & 0.353 & 0.137 & 2.576 & 0.0121 \\
Constant & 1.638 & 0.508 & 3.225 & 0.0019 \\
& Wald statistic $=483.05 \quad$ p-value $=0.001$ \\
\hline
\end{tabular}

Table 3: Results of DRC and SCB Index for selected provinces in both systems over 1999-2013

\begin{tabular}{|c|c|c|c|c|c|c|c|c|c|}
\hline \multirow{2}{*}{\multicolumn{2}{|c|}{ Year/Index }} & \multicolumn{2}{|c|}{ Lorestan } & \multicolumn{2}{|c|}{ Kermanshah } & \multicolumn{2}{|c|}{ Hamedan } & \multicolumn{2}{|c|}{ Ilam } \\
\hline & & Rural & Pastoral & Rural & Pastoral & Rural & Pastoral & Rural & Pastoral \\
\hline \multirow{2}{*}{1999} & DRC & 1.26 & 53.0 & 55.0 & 57.0 & 15.1 & 56.0 & 57.0 & 56.0 \\
\hline & SCB & 0.89 & 56.0 & 0.58 & 64.0 & 83.0 & 59.0 & 66.0 & 61.0 \\
\hline 2000 & SCB & 99.0 & 55.0 & 69.0 & 61.0 & 72.0 & 65.0 & 64.0 & 62.0 \\
\hline \multirow{2}{*}{2001} & DRC & 0.67 & 0.56 & 0.70 & 0.49 & 0.64 & 57.0 & 72.0 & 55.0 \\
\hline & SCB & 0.68 & 0.61 & 0.71 & 0.59 & 66.0 & 63.0 & 72.0 & 61.0 \\
\hline 2002 & SCB & 63.0 & 59.0 & 61.0 & 67.0 & 71.0 & 67.0 & 62.0 & 59.0 \\
\hline \multirow{2}{*}{2003} & DRC & 71.0 & 53.0 & 0.75 & 63.0 & 67.0 & 59.0 & 66.0 & 51.0 \\
\hline & SCB & 70.0 & 58.0 & 0.70 & 66.0 & 71.0 & 66.0 & 69.0 & 57.0 \\
\hline \multirow{2}{*}{2004} & DRC & 59.0 & 58.0 & 71.0 & 68.0 & 68.0 & 65.0 & 49.0 & 59.0 \\
\hline & SCB & 63.0 & 63.0 & 72.0 & 65.0 & 69.0 & 69.0 & 56.0 & 63.0 \\
\hline 2005 & DRC & 0.57 & 0.59 & 47.0 & 62.0 & 56.0 & 63.0 & 44.0 & 61.0 \\
\hline 2007 & SCB & 54.0 & 67.0 & 62.0 & 65.0 & 56.0 & 66.0 & 58.0 & 66.0 \\
\hline \multirow{2}{*}{2008} & DRC & 47.0 & 65.0 & 54.0 & 63.0 & 49.0 & 66.0 & 71.0 & 57.0 \\
\hline & SCB & 56.0 & 67.0 & 63.0 & 64.0 & 59.0 & 69.0 & 70.0 & 61.0 \\
\hline \multirow{2}{*}{2009} & DRC & 55.0 & 65.0 & 62.0 & 69.0 & 49.0 & 69.0 & 56.0 & 51.0 \\
\hline & SCB & 61.0 & 66.0 & 67.0 & 70.0 & 53.0 & 70.0 & 63.0 & 59.0 \\
\hline \multirow{2}{*}{2010} & DRC & 65.0 & 62.0 & 71.0 & 54.0 & 04.1 & 67.0 & 54.0 & 55.0 \\
\hline & SCB & 69.0 & 60.0 & 73.0 & 61.0 & 84.0 & 69.0 & 59.0 & 61.0 \\
\hline \multirow{2}{*}{2011} & DRC & 69.0 & 61.0 & 62.0 & 59.0 & 64.0 & 68.0 & 54.0 & 61.0 \\
\hline & SCB & 71.0 & 69.0 & 67.0 & 64.0 & 69.0 & 70.0 & 61.0 & 66.0 \\
\hline \multirow{2}{*}{2012} & DRC & 56.0 & 52.0 & 58.0 & 55.0 & 49.0 & 62.0 & 64.0 & 63.0 \\
\hline & SCB & 0.61 & 60.0 & 61.0 & 59.0 & 56.0 & 67.0 & 68.0 & 66.0 \\
\hline
\end{tabular}

This subject is seen that dynamic comparative advantage in former years is more increasing than the newer years. This shows the reflex of government policies, climate condition and more 
effective management in the last years. It seems that small ruminant (sheep and goats) are more adapted to the range conditions. It determines the trend of evolution in this profession (small ruminant husbandry) that has been begun first in natural range and then has been gone into the villages. In pastoral system, the ranking of dynamic comparative advantage in selected provinces are Ilam, Lorestan, Kermanshah, and Hamedan and in rural system is as well. So in both systems the Ilam province has the most dynamic comparative advantage. There are two reasons for this subject, first in this province the charge of husbandry buildings is less than other provinces because this province is a war zone and has been used special forgiveness, second is that the weather in Ilam is warmer than other provinces and the numbers of days that the herd is stayed and protected in stable are less and the cost of feeding in less, too.

Table 4 shows the result of EPC and NPC indices for selected provinces in both systems over 19992013. As mentioned in Table 4, the average of it, for pastoral system is more increasing than rural system. So, it has been said that the government support policies, in fact, it supports the upper dynamic comparative advantage. These supporting includes price deviations or market price support (MPS) and paying subside to tradable inputs. The average of NPC is greater in pastoral system than rural system. Since this indicator shows the rate of crops income at market price to the same income at shadow price, so it can be said that the pastoral system has gotten the government supports more than rural system. This support includes price deviating and market price support (MPS).

Table 4: Results of the average of effective protection coefficient (EPC) and nominal protection coefficient (NPC) in selected provinces in both systems

\begin{tabular}{ccccccccc}
\hline \multirow{2}{*}{ Indicators } & \multicolumn{2}{c}{ Lorestan } & \multicolumn{2}{c}{ Kermanshah } & \multicolumn{2}{c}{ Hamedan } & \multicolumn{2}{c}{ Ilam } \\
\cline { 2 - 9 } & Rural & Pastoral & Rural & Pastoral & Rural & Pastoral & Rural & Pastoral \\
\hline EPC & 1.25 & 2.47 & 1.23 & 2.25 & 1.24 & 2.22 & 1.28 & 2.30 \\
NPC & 1.67 & 3.01 & 1.72 & 2.9 & 1.49 & 2.98 & 1.42 & 3.03 \\
\hline
\end{tabular}

\section{Conclusion}

Increasing logic and scientific productivity and responsibility to use ranges for small ruminant husbandry, is applied in many of countries at present time, and this profession is economic and profitable. Today in some of countries animal crops are produced in a mix system include small ruminants and ranges. So application a dynamic and scientific system include small ruminant and ranges can be helped to increase the productivity and progress in this profession. Our finding indicates that the pastoral system have dynamic advantage more than rural system in Iran. There are several reasons to this issue that including 1-Expansion of consumption markets, the ability of presenting in various market and direct supplying the crops, 2-Deleting some of interval crops distribution, 3- Reduction the fix cost for example husbandry buildings and stables, and 4Reduction the variable cost for example less supplementary forage, less the charge of veterinary and etc.

Based on our findings, to increase the productivity in the small ruminant husbandry and pastoral system, recommended that the Iran's government design and preform the effective and scientific management plan to protect natural ranges. Also, apply the plan that keep the scientific and logic proportion between numbers of domestic animals and natural ranges. It is a very important factor that must consider by managers and users, because this balance is not seen at present times. For example in Iran this rate is 2.2 , it means that the rate of number the domestic animals to ranges capacity is 2.2. This shows that the numbers of small ruminant are more increase than scientific capacity of range. This problem must be solved. It is suggested that the government do cession some of ranges to pastoralist to establishing the possession sense by them and more protecting the ranges.

\section{References}

Abedi S, Peykani GH R and Hosseini SS (2009). Determining comparative advantages of corn in optimal cultivation pattern in Khuzestan province. Research Economy and Agricultural Development. 1(39):85-97. [In Persian]. Available online at: http://ijaedr.ut.ac.ir/article_19890_bf1c2e8d4004b1cec30ea 17dc0c2774b.pdf

Ashraphi M, Karbasi G R and Sadrileshrafi S M (2009). Comparative advantage of Iranian raisin production and exports. Iranian Journal of Agricultural Economics and Development, 58(2): 39-59. [In Persian]. Available online at: http://aead.agri-peri.ir/

Bostaki M (2009). Corresponding of government support policies in agricultural sector. Iranian Journal of Animal Science Journal. 73(1): 11-20. [In Persian]. Available online at: www.sid.ir/fa/VEWSSID/J_pdf/560138573d02.pdf

Bruno M (1972). Domestic resource costs and effective protection: Clarification and synthesis. Journal of Political Economy, 80(1): 16-33.

Dahmardeh M (2010). Studied the effects of government policy in selected agricultural crops by Policy Matrix Analysis (PAM) in Sistan and Baloochestan province of Iran. In the $7^{\text {th }}$ Biannual National Conferences of Agricultural Economics, Shiraz, Iran.

Dehghani A (2003). Comparative advantages of the selected agricultural products. Unpublished Research Report, Agricultural Planning, Economics and Rural Development Research Institute, Tehran, Iran. [In Persian].

Eslami M and sherafatmand $H$ (2013). The impact of producer support estimate (PSE) on the productivity: Evidence from maize production. International of Agronomy and Plant Production Journal, 4(6): 1271-1280.

FAO (2001). Policy analysis study: Egypt comparative advantage and competitiveness of major crops. Food and Agricultural Organization of the United Nation, Rom, Italy.

FAO (2016). FAO Statistical Yearbooks: World food and agriculture. Food and Agricultural Organization of the United Nation, Rom, Italy. 
Funing Z, Zhigang X, and Longbo F (2001). An alternative approach to measure regional comparative advantage in China's grain production. In the $45^{\text {th }}$ Annual Conference of the Australian Agricultural and Resource Economics Society, Adelaide, Australia: 1-20. Available online at: ageconsearch.umn.edu/bitstream/125636/2/Funing.pdf

Gonzales LA, Kasryno F, Perez ND, and Rosegrant MW (1993). Economic incentives and comparative advantage in Indonesia food crop production. International Food Policy Research Institute (IFPRI), Washington, USA.

Hayes D J, Kumi A and Johnson SR (1995). Trade impact of soviet reform: A Heckscher- Ohlin-Vanak approach. Review of Agricultural Economics, 17(2): 131-145.

Heckscher EF (1919). The effect of foreign trade on the distribution of income. Ekonomisk Tidskrift, 21: 1-32. Reprinted (1950) in: AEA Readings in the Theory of International Trade, Blakiston, Philadelphia, USA.

I.R. Iran Agriculture Ministry (2013). Agriculture Statistical Yearbook 2011-2012. Economic Statistics Department, Tehran, Iran. Available online at: http://maj.ir/portal/ Home/Default.aspx

I.R. Iran Agriculture Ministry. 2014. Agriculture Statistical Yearbook 2012-2013. Economic Statistics Department, Tehran, Iran. Available online at: http://maj.ir/portal/ Home/Default.aspx

I.R. Iran Central Bank (2013). Household budget survey in urban areas in Iran. Economic Statistics Department, Tehran, Iran. Available online at: http://www.cbi.ir/simplelist/1421.aspx

I.R. Iran Statistical Center (2013). Statistical Yearbook 2012-2013. Presidency of I.R.I. Plan and Budget Organization, Tehran, Iran. Available online at: https://www.amar.org.ir/ english/Iran-Statistical-Yearbook

I.R. Iran Statistical Center (2014). Statistical Yearbook 2013-2014. Presidency of I.R.I. Plan and Budget Organization, Tehran, Iran. Available online at: https://www.amar.org.ir/english/ Iran-Statistical-Yearbook

Jairani E (2010). Corresponding the comparative advantage and the indices of crops animal's supports. Iranian Journal of Agricultural Economics and Development, 49(13): 117-140. [In Persian]. http://www.agri-peri.ir/File/ShowFile.aspx?ID= e2191860-f498-49b7-8b96-7002d8cee377

Jairani E (2010). Corresponding the comparative advantage and the indices of crops animal's supports. Research report, Agricultural Planning, Economics and Rural Development Research Institute, Tehran, Iran. [In Persian]. Available online at: http://www.agri-peri.ir/File/ShowFile.aspx?ID= e2191860-f498-49b7-8b96-7002d8cee377
Jalilpiran H and Naserian ON (2015). Studying the comparative advantage of important agricultural crops in Alborz province. Economic Journal, 3(1): 4-62. [In Persian]. Available online at: http://ejip.ir/article-1-770-fa.pdf

Julai R and Jairani E (2009). Comparative advantage or selfsufficiently? A case study of determining in wheat production of Iran. Iranian Journal of Agricultural Economic Research, 66(1): 145-167. [In Persian]. Available online at: http://aead.agri-peri.ir/browse.php?a_code=A-10-24-204\&slc _lang=fa\&sid=1

Khademaolfazli N (2010). Studying the comparative advantage of producing and exporting the citrus fruits in Mazandaran province. M.Sc. Thesis, Karaj Payam Noor University, Karaj, Iran.

Khandozi E (2013). The theory of porter in trading and competing advantage. Strategy Journal, 4(1): 84-102. [In Persian]. Available online at: http://www.ensani.ir/storage/Files/ 20101210194214-52.pdf

Krueger AO (1991).The political economy of agricultural price policy: Volume 5, a synthesis of the political economy in developing countries. Johns Hopkins University Press for World Bank, Baltimore, Maryland, USA.

Mehrabiboshrabadi H (2009). Study of policy effects and comparative advantage of crop products in Kerman province. In the $6^{\text {th }}$ Biannual National Conferences of Agricultural Economics, Mashhad, Iran.

Molenberghs G and Verbeke G (2005). Models for discrete longitudinal data. Springer, New York, USA.

Monk E and Pearson SR (1989). The policy analysis matrix for agricultural development. Cornell University Press, Ithaca, New York, USA.

OECD (2007). Agricultural policy in OECD, monitoring and evaluating. Organization for Economic and Cooperative Development, the Financial Assistance of the European Union. Available online at: www.oecd.org/publishing/corrigenda

Ohlin B (1933). Interregional and international trade. Harvard University Press, Cambridge.

Tavakoli A and Sayf A (2001). Studying of comparative advantage and the factors that effect on it in selected crops in Iran. Trading Journal, 3(1): 4-62.

Tsakok I (1990). Agricultural price policy. A Practitioner's Guide to Partial Equilibrium Analysis. Cornell University Press, Ithaca, New York, USA.

Yarahmadi B, Eslami M, and Taherpourdori N (2005). The effects of age and sex on some characteristics of Lori sheep. Iranian Agricultural Science Journal, 7(1): 203-210. 